\title{
THE VALUES OF LOCAL WISDOM IN FOSTERING TEACHER'S SOCIAL COMPETENCY AT AL-HILAL ISLAMIC JUNIOR SECONDARY SCHOOL (MTS) IN TEHORU VILLAGE, CENTRAL MALUKU DISTRICT
}

\author{
Nur Hasanah, Nurul Ulfatin, Bambang Budi Wiyono, Kusmintardjo \\ State University of Malang \\ Email: anureel@yahoo.com
}

\begin{abstract}
ABTRACT
This study aims to analyze and describe the development of teacher's social competency based on local wisdom at Al-Hilal Islamic Junior Secondary School in Tehoru Village. The values of local wisdom community in Central Maluku district was integrated in the development of teacher social competence. This study employed the qualitative approach. The data source consisted of primary and secondary data. The data were collected through observation, interview and documentation. The data were analyzed using interactive model of Miles and Huberman. The focuses of this study were: (1) the values of local community wisdom, (2) the integration of the local wisdom values in the development of teacher's social competence, (3) supporting and inhibiting factors in the development of teacher-based social competence of local wisdom. The study reveals three findings. First, the local wisdom value of the people of Central Maluku is Hidop orang basudara which has philosophical value of ale rasa beta rasa, sagu salempeng pata dua, potong di kuku rasa di daging. The values are implemented in societal life like ;masohi, badati, maano. There are also some belief symbols which is convinced by the society like batu kramat. Second, the values of local wisdom in the development of teacher social competence at Al-Hilal Islamic Junior Secondary School in Tehoru village refer to the values of social attitudes and social systems. The social attitudes are brotherhood, responsibility, mutual caring, and cooperation. Whereas the social system is every activity carried out together. Third, there are three inhibiting factors in the development of teacher social competence: the lack of human resources (HR), both educators and educational staff; lack of facilities and infrastructure, and limited of information. Incontrast, there is a supporting factor in the development of teacher social competence, namely: the role of community to have active participation regarding the progress of education quality.
\end{abstract}

Keywords: local wisdom, teacher's social competence

\section{INTRODUCTION}

The role of a teacher in the community depends on the situation of the society itself, such as the social position of teachers in the community. The social position of teachers can be different from one region with another regions and from one age to another age in accordance with the development of science and technology.

In one area, a teacher sometimes has a high social understanding on his roles in the intellectual life of the community. This can be found in the Central Maluku as in this area, the social position of teachers is aligned with government officials. The teacher's roles are also inseparable from the quality of their communication to the surrounding community. Teachers who have good communication will be highly valued in social status in society, and vice versa. Even in the most respecting community of teachers, it would be very difficult to contribute a lot and get a high social understanding if a teacher has lack of the skills and personality.

Based on the results of previous research conducted by Robinson (1981), it was found that among the people in the lower class, the position of teachers is placed at a special order. Like in rural agrarian society, teachers are ranked second after governmental officials (Mahmud, 2012: 122). Therefore, the teacher should be a good example for the students and the community and thus they are expected to be able to maintain the values of local wisdom that exist in the community. Then Parvez and Shakir (2013) showed that the progress of a country depends on the quality of teachers. When teachers are no longer thinking about the process of learning development then leaders no longer evaluate teacher's performance. Thus, the learning process will not work properly and the graduates produced will not be in accordance 
with the objectives. Furthermore, Alsrhid's research results (2012) reveals that teachers are leaders who are able to transfer experience and knowledge and direct the behavior of learners. This means that teachers play an important role in preparing learners to become good citizens and become agents of social change.

Maluku Province is one of East Indonesia provinces. From a cultural perspective, the Moluccan community has about fifty ethnic and sub-tribal groups. Hence it has rich cultural diversity. It can be seen in so varied languages or dialects. Although it has a considerable degree of diversity, basically Maoluccan's cultural roots are the same, that is based on the cosmological view of siwalima. This view is the core value that shapes the personality of the people of Maluku who have the meaning to acknowledge the differences but still have the awareness that they are brothers. In the local language of Maluku, it is called as hidop orang basudara (living together). This philosophy is potong di kuku rasa di daging, ale rasa beta rasa (I feel what what you feel), and sagu salempeng dipata dua (sago is divided into two). The meaning of hidop orang basudara is pro-existence, that is the sense of belonging, responsibility, sharing, cooperation, help, care , and so forth (Wakano, 2012).

Based on preliminary observation at Al Hilaal Islamic Secondary School in Tehoru village, Central Maluku, it was found that the are some crucial problems. First the ability of teachers as part of society is still low. For example, teachers are unable to write scientific papers as a part of means of communication with the community and there are still teachers who have not been able to solve the problem when there is conflict between communities. Second, the mastery of teachers to the content and learning approach is still low. Third, in order to be a model, a teacher must have knowledge and profesional skill. Fourth, facilities and infrastructure are not adequate in supporting the learning process. In a connection with local wisdom of the community at Tehoru village, it is assumed that the teacher is the highest profession so that teachers in the village is very respected.Therefore, when the teachers do not have commitment, responsibility, and competence in their field, they are likely to have a moral burden to their relationship with
God, the community, and the environment. The problem is that teachers need guidance to add insight and improve their skills while maintaining the values of local wisdom. Based on the research background, the researcher was interested in studying the theme: the values of local wisdom in fostering teacher's social competence at Al-Hilal Islamic Secondary School at Tehoru village, Central Maluku Province, Indonesia. This study aims to analyze and describe the improvement of social competence of teachers of Al-Hilal Islamic Secondary School in Tehoru, Central Maluku Province.

The professional teacher is a teacher who is able to manage himself in carrying out daily tasks (Bafadal, I;1994). Therefore, Samana (1994) states that the existence of a teacher serves as a professional educator at school. In this case, the teacher has a role as an uswatun hasanah, administrator, and community officer. The roles of a professional teacher are as a designer, educator (personality development), manager, administrator, supervisor, innovator, motivator, counselor (self- help solve problems), facilitator (providing technical assistance and guidance), and evaluator (assessing student work) (Uno, HB., 2012).

Rivai and Murni (2011) state that the competence is the ability to do something. The relationship of professional personnel of competence shows the rational acts to fulfill certain specifications in the implementation of educational tasks. The ability of teachers is very important because it is related to the ability to guide learners so that they can master the subject matter maximally. Satori, D. (2010) stated that teachers in teaching and learning process must have qualified, effective, and efficient competence to achieve learning objectives. Therefore, teachers need to be nurtured properly because the function of teachers is to foster and develop the ability of learners professionally in the learning process. Teachers must have the following personality competencies: (1) increase faith and belief in accordance with the religion believed 2) be responsible and develop self-esteem; 3) develop tolerance; 4) be open and democratic; 5) diligent and tenacious in implementing the educational process; 6) able to live the overall educational objectives; 7) mutual respect in social; 8) understanding the various as- 
pects of the self that are positive or negative; 9) develop the profession as an innovator and creator.

Gumelar and Dahyat (2002) purpose some personal competencies of a teacher: (1) knowledge of both social and religious customs; (2) knowledge of culture and tradition; (3) knowledge of the core of democracy; (4) knowledge of aesthetics; (5) social appreciation and awareness; (6) the right attitude to knowledge and work; (7) faithful feeling to human dignity and prestige. Getteng, AR. (2011) states that teachers as professional positions are expected to work to carry out the functions and objectives of the schools. They must have the following personality competencies: (1) steady; (2) stable; (3) adult; (4) understanding and wise; (5) authoritative; (6) noble; (7) be a role model for learners and the community; (8) objectively evaluate own performance, and (9) develop self-reliance and sustainability.

The teacher's social competence is the ability of the teacher to understand himself as an integral part of society so they are able to develop their duties as members of society and citizens. The teacher's social competence is the ability to communicate and socialize effectively with learners, fellow teachers, principals and the community. Furthermore, Sarimaya, F. (2008) argued that social competence is the ability of the teacher as part of the community, who at least has the competence to: a) communicate orally, in writing, and gesture; b) use information and communication technology functionally; c) associate effectively with learners, fellow educators, education personnel, parents / guardians of learners; d) associate politely with the surrounding community.

The social competencies that teachers need to have in order to communicate and get along effectively in both the school and community environment include; : a) having knowledge of customs both social and religious; b) having knowledge of culture and tradition; c) having knowledge on the core of democracy; d) having knowledge of aesthetics; e) having social appreciation and awareness; f) having the right attitude to knowledge and work; g) having faithful to human dignity.

The process of understanding the interaction (communication) can be divided into two models, namely: a) Intrapersonal Communications Skill which is communication into the self (the introduction of identity) for example through meditation, the introduction of conscience, free will, and creative imagination. The intrapersonal communication process enters through the stimulus process into the human subconscious mind; b) Interpersonal Communication Skill which is a face-to-face interaction between two or more people, in which the sender can deliver the message directly and the recipient of the message can receive and respond directly as well.

One of the functions of the personal manager is staff development, in which in this case the school is required to improve the competence of teachers. Castallo (1992: 129) states that: this broader meaning of staff development encompasses all those activities in wich professional staff members engage to enhance their ability to perform their jobs and/or make them more productive employes. This can include activities as a college course work, district-sponsored staff development trainings sessions, activites supported by teacher centers, mentoring, peer coaching, clinical supervision, action research involving professionals, institutes, seminars, and individually determined professional or personal development plans.

The professional enhancement strategy of the teacher is to conduct a teacher training which is one of the functions of education of human resource management. Sharif (1991: 12) suggested that training is a process to help the workforce shape, improve and alter its knowledge, attitude and behavior skills in order to achieve certain standards in accordance to what is demanded by its position.Meanwhile, Rohani (2004: 72 ) stated that teacher training is a series of professional service assistance provided by more skilled people (principals, supervisors, experts) to teachers in order to improve their competence, so that the planned educational objectives can be achieved.

The main character of a learner's organization is always to look at internal and external changes that are followed by an appropriate adaptation in order to maintain its own existence. It will also affect the school as a social system because the school bureaucracy that has been stained with a rigid bureaucracy that does not recognize the social values of the school commu- 
nity. By viewing the school as a social system, it has the purpose of emphasizing the study of psychological interpersonal relationships among members in the school system. The components can be described on Figure 1.

Based on the model on Figure 1, it can be explained that the school as a social system. It is divided into two parts namely; a) organizational dimensions, and b) personal dimensions. The organizational dimension is divided into three parts, namely institutions, roles, and expectations.

While the personal dimension is divided into three parts, namely individual (teacher), personality, and disposition of expected needs. The role of the school serves as an organizational dimension that has a role to attain the behavior that is expected to be displayed as part of the social behavior and individual teachers as the personality dimension that has the need for character to serve students as a form of social behavior.

Teacher development should be a program designed by schools and supporting organizations and education providers as well as supported by activities held by teachers. Orlosky in prihatin(2005: 40-41) said that teacher development is a process designed by schools to promote the quality and quantity of staff members needed to solve problems, in order to achieve the goals of the school. Teachers's training should be implemented through several steps, namely continuous, sustainable, and the supervisor should not know bored. According to Dugan in prihatin (2005: 41), it is suggested that the steps of teacher development include planning, implementation and evaluation activities.

Personality and social competence of teachers according to Makawimbang (2011: 137) can be measured from several indicators, including: a) Mastering the educational foundations; b) Managing teaching-learning interactions; c) Assessing student achievement for the purposes of the lesson objectively; d) Recognizing the functions of counseling and guidance services in schools, including: (1) recognizing the functions and services of guidance and counseling programs; (2) providing counseling and guidance services; e) Knowing and administering the school administration; f) Understanding the principles and interpreting the results of educational research for the purposes of teaching.

The meaning of local wisdom can be understood as local ideas (wise), full of wisdom, good value, embedded and followed by members of society (Echols and Syadily, 2000). Culture contains a very broad and complex meaning and understanding. One of the various perspectives on culture, including local culture according to Alexander (2006) in Watloly (2012: 37) is defined as culture as the way a group of people who live, think, feel, organize themselves, and share life together.

Local wisdom for Maluku people is known as the area of a thousand islands with the character of the territorial sea which is very dominant, which is $92 \%$ and studded thousands of small islands, land area of only $7.6 \%$ and various sociocultural features. As a community of small islands, the Maluku islands have unequal distribution of population, social behavior of coastal, inland and border island communities and cultured islands. The cultural features are not merely agrarian, but agrarian-marine (cultured by sea-land ). (Watloly, 2012: 118)

The forms of fraternity of local wisdom in Central Maluku namely Alifuru tribe, includes:

\section{Nomothetic dimension (Organizational)}

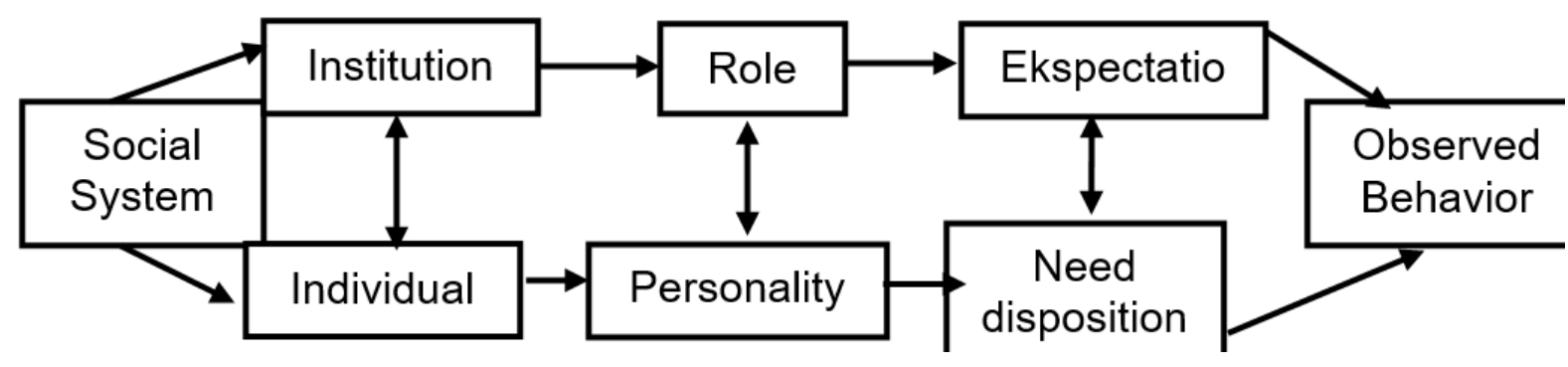

Ideographic dimension (Personality)

Figure 1: Analysis model of social system in Education administration science Adopted from Getzels-Guba (1958) in Owens (1991:68). 
1) Pela. It consists of a variety; 2) gandong is geneologis fraternity between two or more villages; 3) Masohi, Badati, and Maano refers to Masohi which is the cooperation between citizens who are helping the citizens who carry out an activity (non-transactional in nature) .Badati is meaningful mutually cooperation to assist a job affairs that must be done together with dependents shared burdens (energy, goods and materials). Maano is a profit-sharing partnership which is a habit of helping each other and taking on a job whose results are then shared with those who agree. 4) Sasi is a kind of customary law related to the prohibition to take, whether forest products or seafood within a certain period set by the government of the country. Sasi is also a protective measure for the continuation of the village economy in order to keep the food supply secure. Sasi's mechanisms is implemented in saniri negeri and kewang. Meeting's decisions are announced by marinyo which is then followed by kewang who maintain and supervise the implementation of the sasi until the time comes for the agreement to expire in accordance with the deadline, and it is celebrated with makang patita (eat together from the result of sasi).

\section{METHODS}

This study employed descriptive qualitative approach. The data source consisted of primary and secondary data. The data were collected through observation, interview and documentation. To check, the data validity, it is conducted through the following steps; a) Degree of Trust (credibility); b) Transferability; c) Dependability; and d) Confirmability. The data were analyzed using interactive model of Miles and Huberman.

\section{RESULTS AND DISCUSSION}

\section{Local wisdom values of central Maluku society}

Based on the findings of the research, it shows that the people of Central Maluku generally uphold the values of brotherhood in accordance with the philosophical roots of Moluccan life, namely "hidop orang basudara" which describes the meaning of brotherhood. The value has philosophical value of ale rasa beta rasa, potong dikuku rasa di daging, sagu salempeng pata dua.These philosophical values have a universal meaning, in which the sense of responsibility for mutual help, the value of brotherhood, togetherness, and sacrifice are implemented in pela, gandong, masohi, cure, and maani. For more details, it can be seen in Figure 2 , as follows.

\section{Values of Local Wisdom in Fostering Teacher's Social Compentions}

Based on the results of data exposure, research findings on local wisdom values are integrated in improving teacher's social competence, showing school activities and community activities integrated into work programs with the aim of preserving the cultural values of local communities that uphold the values of local wisdom " "Masohi. Teachers in demand can adapt to the community environment, especially the immigrant teachers. Therefore, the principal combines community activities with activities at school without disturbing the learning process, for example in terms of work called manyimpang nagri, b) Maani is the cooperation of individual interests and non-transactional nature such

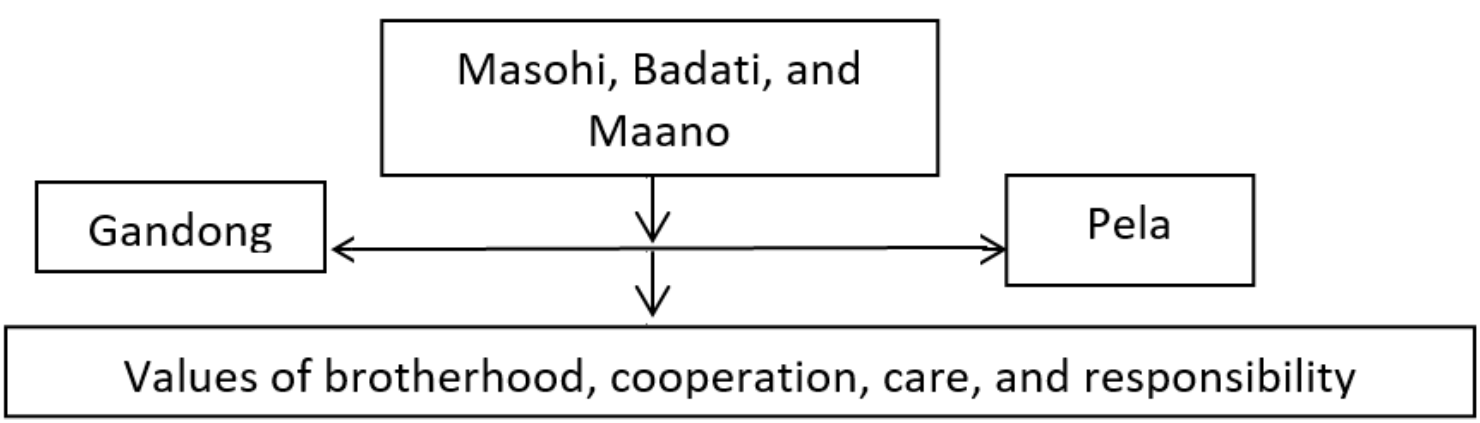

Figure 2.Contextual diagram on the forms of local wisdom 
as helping people to celebrate, examples of kekuloyang activities to bring a pan on the head of the contents of raw and ready-to-eat food stuff done for generations. c) Badati is the form of fraternity which is the right and obligation between each other to help each other. For more details, it can be seen in Figure 3, as follows.

\section{Inhibiting Factors and Supporting elements in the Development of Teacher's Social Competencies}

The findings of the research indicate that the inhibiting factors are: 1) the lack of human resources, both on the educator and the education personnel; 2) lack of facilities and infrastructure; 3) limited information. Therefore, teachers sometimes find it difficult to get information related to active learning methods. Supporting factors from the school as well as from the community and education office are: 1) the community voluntarily participate in helping the progress of education quality as there are people who are ready to become administrative personnel; 2) the community can submit a proposal for assistance to the education office; 3 ) teachers are included in training program or learning workshop. For more details can be seen in Figure 4, as follows:

\section{CONCLUSION}

The study reveals three findings. First, the value of local wisdom refering to Hidop orang basudara is implemented in the social life of the community including ; pela, gandong, masohi, badati, maano. Second, the values of local wisdom that are integrated in improving the teacher's personality and social competence refers to the values of responsibility, caring, cooperation, brotherhood, harmony, and mutual care like masohi which is teaching the community activities and traditional ceremonies. The form of personality competence of teachers in carrying out their duties responsibly. Meanwhile, the form of the teacher's social competence is mutual care and help; Maano: an agreement to help each other and work together; Badati: the social interaction between the community and teachers to help each other to fulfill our responsibilities as Kita Orang Basudara (we are all brothers). Third, the inhibiting factors in the development of

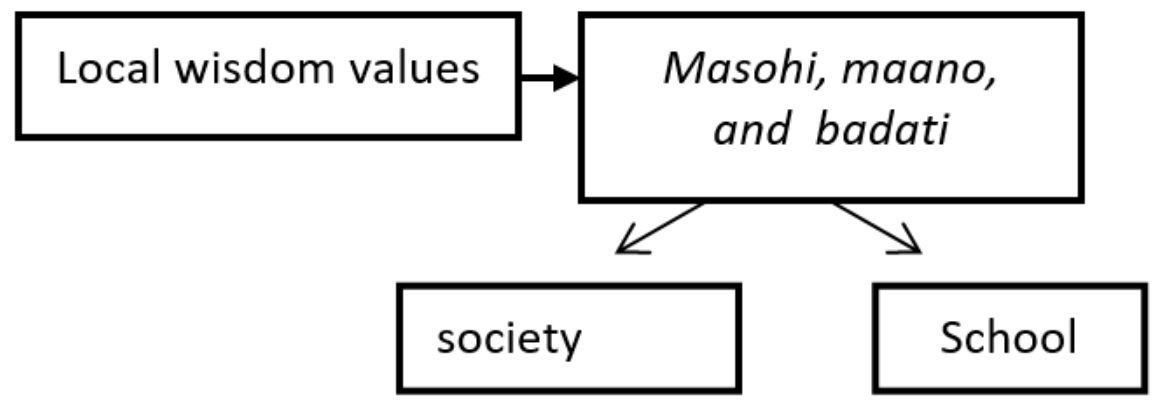

Figure 3. Contextual Diagram on local wisdom values in fostering teacher's competence

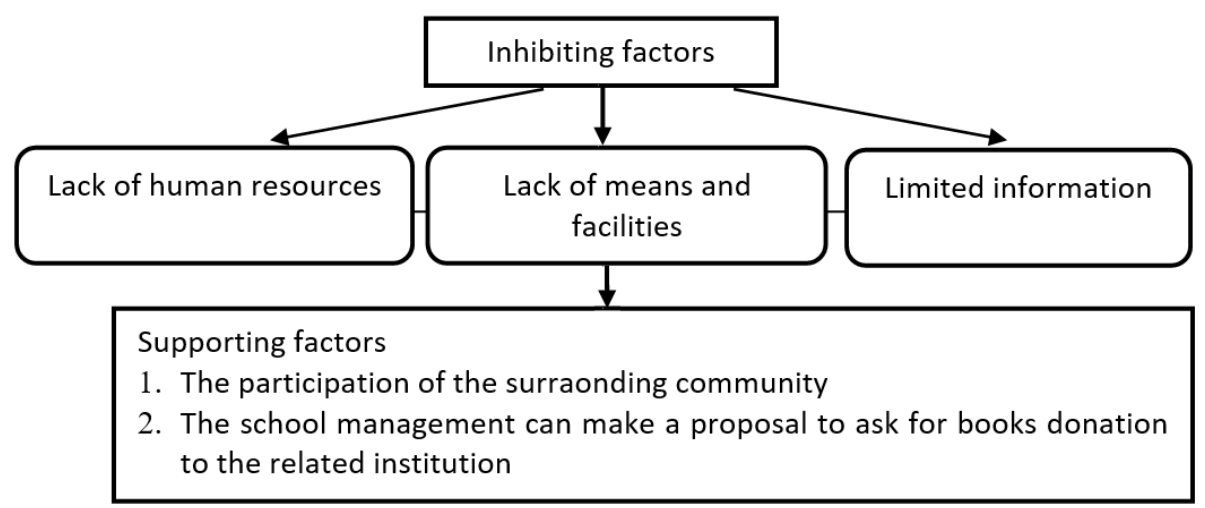

Figure 4: The Context of problem dan solution. 
teacher's social competencies are: lack of human resources; lack of facilities and infrastructure; and limited information. Meanwhile, the supporting factors: are communities play an active role in the advancement of the quality of education; Islamic school in this case MTs al hilaal of tehoru village can submit a proposal to the related institution; and teachers are included in the workshop.

\section{REFERENCES}

Sutirah, (2014). Kepemimpinan Kepala Sekolah Dalam Meningkatkan Kompetensi Guru Sekolah Dasar (Studi Multi Kasus di SDI Surya Buana dan SDN Tlogomas 2 kota Malang). Tesis tidak diterbitkan. Malang: Pascasarjana Universitas Negeri Malang.

Parves, M. \& Shakir, M, (2013), Attitudes of Prospective Teachers towards Teaching Profession,Journal of Education and Practice, (Online), 4 (10): 172-178, www. iiste.org, diakses 10 Desember 2017.

Wakano, A. Watloliy, A. Tawainella, N. Salatalohi, F. Ufi, A. J. (2012). Menggali Sejarah dan Kearifan Lokal Maluku. Jakarta: Cahaya Pineleng.

Bafadal, I. (1994). Proses Perubahan di Sekolah: Studi Multi Situs pada Tiga Sekolah Dasar yang Baik di Sumekar.Disertasi tidak dipublikasikan. Malang: PPs IKIP Malang.

Samana. (1994). Profesionalisme Keguruan. Yogyakarta: Kanisius.

Uno, HB. (2012). Profesi Kependidikan, Problem Solusi, dan Reformasi Pendidikan di Indonesia.Cet; IX. Jakarta: Bumi Aksa.

Rivai, V \& Murni, S. (2011). Education Management.Jakarta: Rajawali Press

Satori, D. (2010). Profesi Keguruan. Jakarta: Universitas Terbuka.

Gumelar dan Dahyat. (2002). Kompetensi Kepribadian Sosial dan Professional. Tersedia: http://assesmentsainssatoe.blogspot. com/2012/05/kompetensi-kepribadian-sosial-dan.html\#axzz2jA75N5wQ. Diakses 09Agustus 2017

Getteng, AR. (2011). Menuju Guru Profesional dan Beretika,Cet; III. Yogyakarta:Grha Guru Printika.
Sarimaya, F. (2008). Sertifikasi Guru. Bandung: Yrama Widya.

Castallo, R.T. (1992). School Personnel Administration A Practiioner's Guide. Boston, London, Toronto, Sidney, Tokyo, Singapore: Allyn Bacon.

Syarif, R. 1991. Manajemen Latihan dan Pembinaan. Bandung: Angkasa.

Rohani, N. K. (2004). Pengaruh Pembinaan Kepala Sekolah dan Kompensasi Terhadap Kinerja Guru SLTP Negeri di Kota Surabaya. Jurnal Pendidikan Dasar.

Owens, R. G. (1991). Organizational Behavior In Education. Boston, London, Toronto, Sydney, Tokyo, Singapore: Allyn and Bacon.

Prihatin, T. (2005). Peningkatan Mutu Pendidikan Melalui Implementasi Pembinaan Guru di Era Otonomi Daerah. Jurnal Pendidikan Dasar. 14, (1), 37- 47. Online: www.dikdas.jurnal.unesa. ac.id. Diakses tanggal 23 Oktober 2014

Makawimbang, H. J. (2011). Supervisi dan Peningkatan Mutu Pendidikan.Bandung: Alfabeta

Echols, M \& Syadily, H. (2000).An EnglishIndonesian Dictionary. Jakarta: PT Gramedia

Watloly, Aholiab. (2012). Memperkuat Falsafah Hidup Orang Basudara, dalam Kumpulan Tulisan Berlayar dalam Ombak Berkarya untuk Negeri. Ambon: Ralahalu Institut.

Strauss \& Corbin Yuliet. (2003). Dasar-Dasar Penelitian Kualitatif. Penyadur Djunaidi Ghony. PT. Bina Ilmu. Surabaya.

Denzin, Norman, K. And Yvonna, S. Lincoln (eds)., (1994). Handbook of Qualitative Research Sage Publications. International Educational and Professional Publisher: Thounsand Oaks: London New Delhi.

Miles, Matthew B. Qualitative Data Analysis: $A$ methods source book / Matthew B. Miles, A. Michael Huberman, Johnny Saldaña, Arizona State University. Third edition. Copyright (C) 2014 SAGE Publications, Inc. 